\title{
PERILAKU KONSUMEN DALAM MENGGUNAKAN JASA TRANSPORTASI OJEK ONLINE DI SEMARANG
}

\author{
Vino Bagus Setyo Adi \\ Edy Suryawardana \\ Fakultas Ekonomi Universitas Semarang (USM)
}

Diterima: April 2018. Disetujui: Juli 2018. Dipublikasikan: Oktober 2018

\begin{abstract}
This study aims to find out and get information about the implementation of consumer behavior in using the online taxibike transportation services Go-Jek in Semarang.

Technique of taking research subject or informant used is purposive sampling and snowball sampling, with criterion: 1) Informant is smartphone user, 2) Informant has Go-Jek application on their smartphone, 3) Informant ever been used Go-Jek services in Go-Jek application, 4 ) Aged 19 years and over, because the age is considered enough to provide opinions and statements that do not change. Informants in this study amounted to five people. More specifically, the five informants selected in this study were informants who had the different number of frequencies using Go-Jek's online taxibike services, which meant that the informant had his own point of view and uniqueness. With data collection techniques used are interviews, and data analysis techniques used are qualitative descriptive by constant comparative method. In the end, the validity check of the data used is source triangulation. Of the five informants, it is known that one of the informants into source triangulation is Veronica Mutisari, because it has been using Go-Jek services for more than a year.

Based on the results of the research, it was found that according to informants, consumer behavior in using the online taxibike transportation services of Go-Jek in Semarang influenced by internal factors which include: 1) Profession; 2) Lifestyle; 3) Past experience; and 4) likes, while internal factors that do not affect consist of: 1) Age; 2) Education; 3) Character or Personality. In addition, it was found that consumer behavior in using the online taxibike transportation services Go-Jek also influenced by external factors that is 1) Friends; 2) Promotion; 3) Price; and 4) Availability of services, while external factors that do not affect are: 1) Family; 2) Social status; 3) Culture; 4) Accident insurance.
\end{abstract}

Keywords: consumer behavior, internal factors, external factors, transportation services, Go-Jek.

\begin{abstract}
ABSTRAK
Penelitian ini bertujuan untuk mengetahui dan mendapatkan informasi tentang implementasi perilaku konsumen dalam menggunakan jasa transportasi ojek online Go-Jek di Semarang.

Teknik pengambilan subjek penelitian atau informan yang digunakan adalah purposive sampling dan snowball sampling, dengan kriteria: 1) Informan merupakan pengguna smartphone, 2) Informan memiliki aplikasi Go-Jek pada smartphone mereka, 3) Informan pernah menggunakan layanan di aplikasi Go-Jek, 4) Berusia 19 tahun keatas, karena usia tersebut dinilai sudah cukup mampu memberikan pendapat dan pernyataan yang tidak berubah-ubah. Informan pada penelitian ini berjumlah lima orang. Secara lebih spesifik, kelima informan yang dipilih dalam penelitian ini adalah informan yang memiliki jumlah frekuensi penggunaan layanan jasa transportasi ojek online Go-Jek yang berbeda, hal itu dimaksudkan agar informan mempunyai sudut pandang dan keunikan
\end{abstract}


tersendiri. Dengan teknik pengumpulan data yang digunakan adalah wawancara, serta teknik analisa data yang digunakan adalah deskriptif kualitatif dengan metode perbandingan tetap atau constant comparative method. Pada akhirnya, pemeriksaan keabsahan data yang digunakan adalah triangulasi sumber. Dari kelima informan, diketahui bahwa salah satu informan menjadi triangulasi sumber adalah Veronica Mutisari, karena sudah menggunakan layanan jasa Go-Jek lebih dari setahun.

Berdasarkan hasil penelitian, didapatkan bahwa menurut informan, perilaku konsumen dalam menggunakan jasa transportasi ojek online Go-Jek di Semarang dipengaruhi oleh faktor internal yang meliputi: 1) Pekerjaan; 2) Gaya hidup; 3) Pengalaman masa lalu; dan 4) Rasa suka, sedangkan faktor internal yang tidak mempengaruhi terdiri dari: 1) Usia; 2) Pendidikan; 3) Sifat atau Kepribadian. Selain itu juga, ditemukan bahwa perilaku konsumen dalam menggunakan jasa transportasi ojek online Go-Jek juga dipengaruhi faktor eksternal yaitu 1) Teman; 2) Promosi; 3) Harga; dan 4) Ketersediaan layanan, sedangkan faktor eksternal yang tidak mempengaruhi ialah: 1) Keluarga; 2) Status sosial; 3) Budaya; 4) Asuransi kecelakaan.

Kata kunci: perilaku konsumen, faktor internal, faktor eksternal, jasa transportasi, Go-Jek.

\section{PENDAHULUAN}

Latar Belakang Masalah

Di era modern ini masyarakat mempunyai aktivitas yang beragam dan untuk memenuhi aktivitas tersebut masyarakat memerlukan adanya transportasi sebagai alat penunjang/alat bantu dalam melakukan aktivitasnya. Oleh karena itu pengusaha jasa transportasi berlomba-lomba menggaet konsumennya dengan peningkatan pelayanan, kemudahan pemesanan, kenyamanan armada, ketepatan waktu dan lain sebagainya. Di Indonesia banyak dijumpai sepeda motor juga melakukan fungsi sebagai kendaraan umum yaitu mengangkut orang/barang dan memungut biaya yang disepakati, moda transportasi jenis ini dikenal dengan nama ojek.

Seiring dengan berkembangnya teknologi saat ini terdapat aplikasi yang mengenalkan layanan pemesanan ojek menggunakan teknologi dan memakai standar pelayanan. Sebelumnya ojek memakai sistem pangkalan berbasis wilayah di tikungan dan mulut-mulut gang. Pengendara ojek dari wilayah lain tidak bisa sembarangan "mangkal" di suatu wilayah tanpa ijin dari pengendara ojek di wilayah tersebut. Untuk menggunakan jasa ojek pun, pemakai jasa harus membayar kontan dan tak jarang sering tawar-menawar. Saat ini sudah banyak penyedia jasa ojek online yang dikenal dengan nama Go-Jek, Uber, Blu-Jek, Taksi Roda Dua, Grab Bike, Ojek Syar'i, Bang Ojek Aja. Semua memberikan pelayanan yang hampir sama mulai dari 
mengantarkan orang dengan biaya yang berbeda-beda, namun dengan sistem pemesanan yang sama yaitu pemesanan melalui aplikasi telepon genggam maupun website.

Salah satu perusahaan jasa transportasi yang sedang berkembang di kota Semarang adalah Go-jek. PT. Go-jek Indonesia didirikan pada tahun 2011 oleh Nadiem Makarim dan Michaelangelo Moran. Perusahaan ini bergerak di bidang jasa layanan transportasi sebagai perantara yang menghubungkan antara para pengendara ojek dengan pelanggan. Pada Januari 2015, perusahaan meluncurkan aplikasi mobile Go-jek berbasis location-based search untuk telepon genggam berbasis android dan iOS . Melalui aplikasi ini, pengendara ojek dapat melihat pesanan yang masuk dan lokasi pemesannya untuk ditanggapi, dan pelanggan dapat memantau posisi pengendara ojek yang menanggapi pesanan. Go-jek kini telah beroperasi di 21 provinsi dan mencakup 50 kota di Indonesia, seperti Medan, Jabodetabek, Semarang, Yogyakarta, Surabaya, Bali, Makassar, Balikpapan dan di kota lain-lainnya. Jasa dan layanan Gojek berkembang tidak hanya sebagai transportasi orang (transport), tetapi juga dapat digunakan sebagai pengantar barang, dokumen, ataupun paket (instant courier), sebagai mitra perusahaan online maupun offline yang membutuhkan pengantaran pada hari yang sama (shopping), bahkan yang terbaru dapat digunakan sebagai pengantar makanan yang dipesan (food delivery).

Go-Jek menjadi pionir layanan ojek berbasis aplikasi mobile melalui layanan Go-Ride-nya. Dengan ini, pengguna aplikasi Go-Jek cukup memesan ojek melalui aplikasi mobile secara online dan nantinya akan dijemput oleh supir ojek yang merespon pesanan pengguna atau calon penumpang. Transaksi pembayaran dilakukan saat pengguna sampai ke tujuan kepada supir ojek. Tarif yang dikenakan bervariasi berdasarkan jarak yang ditempuh atau berdasarkan flat rate yang diberlakukan. Beberapa perusahaan yang menjadi pesaing Go-Jek adalah GrabTaxi, dengan GrabBike-nya, dan Blu-Jek. Kedua perusahaan ini memiliki layanan yang serupa dengan layanan Go-Ride dari Go-Jek.

Di kota Semarang, Go-Jek sudah mulai beroperasi sejak tahun 2016. Ada beberapa transportasi online yang dapat ditemukan di Semarang, 
diantaranya adalah Go-Jek, Uber, dan Grab. Hampir semua orang sudah mengetahui keberadaan Go-Jek dan banyak juga yang memanfaatkan Go-jek tersebut untuk memenuhi kebutuhannya. Awalnya GoJek hanya tersedia di Jakarta saja, namun sekarang sudah terdapat di beberapa kota besar lainnya. GoJek juga sudah dapat ditemukan di kota Semarang.

Selain GoJek, ada juga transportasi online yang dapat ditemui di Semarang yaitu Uber dan Grab. Layanan transportasi inilah yang sering diakses dan digunakan oleh para konsumen atau pengguna jasa transportasi. Bahkan para konsumen di Semarang menjadikan aplikasi transportasi online tersebut sebagai pilihan untuk menghindari kemacetan yang sering terjadi di Semarang. Karena dianggap menggunakan transportasi melalui aplikasi transportasi online lebih mudah, lebih praktis, dan juga dan tidak perlu menunggu waktu lama sehingga mayoritas konsumen atau masyarakat di kota Semarang lebih memilih untuk menggunakannya.

Jika dilihat dari fenomena yang peneliti tangkap, maka bisa disimpulkan bahwa jasa transportasi ojek online Go-Jek dipilih mayoritas konsumen di Semarang, dengan adanya peningkatan konsumsi jasa transportasi ojek online Go-Jek sekarang ini mengindikasikan bahwa adanya peningkatan jumlah konsumen potensial yang membeli atau mengonsumsi layanan jasa transportasi ojek online Go-Jek tersebut. Perilaku pembelian konsumen tersebut menunjukkan peningkatan keinginan dari konsumen untuk menggunakan layanan jasa transportasi ojek online Go-Jek dipicu oleh berbagai faktor. Mengenai faktor yang memengaruhi perilaku konsumen dalam mengonsumsi atau menggunakan layanan jasa transportasi ojek online Go-Jek ini didukung teori yang dikemukakan oleh Kotler dan Amstrong (2015:197) yang menyebutkan faktor-faktor yang memengaruhi perilaku konsumen itu terdiri dari budaya, sosial, pribadi, dan psikologi.

Perilaku konsumen berserta berbagai faktor yang memengaruhinya dianggap penting oleh perusahaan karena keberlangsungan hidup suatu perusahaan bergantung kepada perilaku konsumen, terutama perilaku konsumen dalam melakukan pembelian. Oleh karena itu, memahami perilaku konsumen sangatlah 
penting demi operasional perusahaan yang berkesinambungan dalam jangka waktu yang lama, sedangkan untuk memahami perilaku konsumen tidaklah mudah, karena konsumen memutuskan untuk melakukan pembelian terhadap suatu produk atau jasa pada dasarnya adalah karena adanya kebutuhan yang bervariasi sesuai dengan usia, pendapatan, pendidikan, dan selera.

Memahami perilaku konsumen sangat berguna bagi perusahaan, karena dengan mempelajari perilaku konsumen, maka perusahaan dapat mengetahui apa yang diinginkan oleh konsumen. Selain itu perusahaan juga dapat mengantisipasi perilaku konsumen di masa yang akan datang melalui penerapan strategi pemasaran yang tepat. Dalam kajian tentang perilaku konsumen, proses keputusan pembelian adalah cermin dari perilaku konsumen tersebut.

Perusahaan akan mengetahui kapan konsumen pertama kali mengenal kategori dan produk mereka, apa kepercayaan merek mereka, seberapa jauh keterlibatan mereka dengan produknya, bagaimana mereka membuat pilihan tentang merek mereka, dan seberapa puas mereka setelah melakukan pembelian.

Rumusan masalah dalam penelitian ini adalah sebagai berikut: Bagaimana implementasi perilaku konsumen layanan jasa transportasi di Semarang dalam menggunakan jasa transportasi ojek online Go-Jek. Atas dasar rumusan masalah tersebut, maka pertanyaan penelitian adalah sebagai berikut faktor-faktor apa saja yang mempengaruhi perilaku konsumen dalam menggunakan jasa transportasi ojek online Go-Jek ? Sedangkan tujuan penelitian ini adalah uUntuk mengetahui faktor-faktor apa saja yang mempengaruhi perilaku konsumen dalam menggunakan jasa transportasi ojek online Go-Jek.

\section{TELAAH PUSTAKA}

\section{Landasan Teori}

\section{Perilaku Konsumen}

Tujuan dari setiap kegiatan pemasaran adalah memuaskan kebutuhan dan keinginan konsumen atau pelanggan sasaran. Oleh karena itu, konsumen mempunyai arti yang sangat penting bagi perusahaan. Memahami perilaku konsumen tidaklah mudah, karena konsumen memutuskan untuk melakukan 
pembelian terhadap suatu produk atau jasa pada dasarnya adalah karena adanya kebutuhan yang bervariasi sesuai dengan usia, pendapatan, pendidikan, dan selera.

\section{Pengambilan Keputusan Dalam Pembelian}

Pengambilan keputusan merupakan sebuah proses kognitif yang mempersatukan emosi, pikiran, proses informasi dan penilaian-penilaian secara evaluatif. Situasi dimana keputusan diambil mendeserminasikan sifat exact dari proses yang bersangkutan. Misalnya, pembelian suatu jenis produk tertentu oleh seorang konsumen biasanya memerlukan pemecahan masalah secara efektif. Proses tersebut mungkin memerlukan waktu berhari-hari lamanya dengan suatu seri keputusan yang dapat diidentifikasi, yang dibuat pada berbagai tahapan proses pengambilan keputusan.

Keputusan untuk membeli suatu produk lebih-lebih yang berdampak pada orang banyak akan memerlukan banyak orang yang ikut campur dalam proses pengambilan keputusan. Secara garis besar kita dapat membedakan beberapa peranan yang mungkin dimainkan oleh orang dalam sebuah keputusan membeli. Menurut Kotler (2016:256), pengambilan keputusan dalam pembelian meliputi lima tahap:

1. Pengambil inisiatif

Merupakan orang yang pertama-tama menyarankan atau memikirkan gagasan membeli produk atau jasa tertentu.

2. Orang yang mempengaruhi

Merupakan seseorang yang memberikan pengaruh, pandangan atau nasehat yang diperhitungkan dalam pembuatan keputusan terakhir terhadap produk yang dipilih.

3. Pembuat keputusan

Pembuat keputusan adalah yang pada akhirnya menentukan sebagian besar atau keseluruhan dalam keputusan membeli apakah jadi membeli, apa yang dibeli, bagaimana cara membelinya, dan dimana pembeli berada. 
4. Pembeli

Pembeli adalah seseorang yang melakukan pembelian yang sebenarnya terhadap produk atau jasa.

5. Pemakai

Pemakai adalah seseorang atau beberapa orang yang menikmati atau memakai produk atau jasa.

\section{Tahap-tahap Proses Pengambilan Keputusan Pembelian}

Proses keputusan pembelian merupakan tahapan-tahapan dalam proses pengambilan keputusan pembeli. Untuk memudahkan perusahaan dalam meneliti proses keputusan pembelian konsumen maka digunakan model tahapan dari proses pembelian.

1. Pengenalan Masalah

Pengenalan masalah merupakan tahap pertama proses pengambilan keputusan pembeli dimana konsumen mengenali suatu masalah atau kebutuhan. Proses pembelian dimulai ketika mengenali masalah atau kebutuhan. Kebutuhan tersebut dapat dicetuskan oleh rangsangan internal atau eksternal. Para pemasar perlu mengidentifikasi keadaan yang memicu kebutuhan tertentu dengan cara mengumpulkan informasi dari sejumlah konsumen, para pemasar dapat mengidentifikasi rangsangan yang paling sering membangkitkan minat akan kategori produk tertentu.

\section{Pencarian Informasi}

Pencarian informasi merupakan tahap proses pengambilan keputusan pembeli dimana konsumen telah tertarik untuk mencari lebih banyak informasi. Konsumen yang terangsang kebutuhannya akan terdorong untuk mencari informasi yang lebih banyak. Oleh karena itu para pemasar harus memperhatikan sumber-sumber informasi utama yang menjadi acuan konsumen dan pengaruh relatif tiap sumber tersebut terhadap keputusan pembelian selanjutnya. Menurut Kotler (2016:225) menggolongkan sumber informasi 
konsumen kedalam empat kelompok, yaitu:

a. Sumber pribadi: dari keluarga, teman, tetangga, dan kenalan.

b. Sumber komersial: dari iklan, wiraniaga, penyalur, kemasan, pajangan.

c. Sumber publik: dari media massa dan organisasi penentu peringkat.

d. Sumber pengalaman: dari pengkajian dan pemakaian produk.

Melalui pengumpulan informasi, konsumen dapat mempelajari trend merek-merek yang ada di pasar, yang memiliki tingkat bersaing. Informasi produk juga memberikan gambaran kepada konsumen, sehingga perusahaan perlu menerapkan strategi yang dapat memasukkan mereknya ke dalam kumpulan kesadaran, kumpulan pertimbangan, kumpulan pilihan dan kumpulan calon pembeli melalui identifikasi merek-merek lain dalam kumpulan pilihan konsumen, sehingga perusahaan dapat merencanakan strategi pengembangan produk.

\section{Evaluasi Alternatif}

Evaluasi alternatif merupakan tahap dalam proses pengambilan keputusan pembelian dimana konsumen menggunakan informasi untuk mengevaluasi merek-merek alternatif dalam satu susunan pilihan. Menurut Kotler (2016:226) konsep dasar yang membantu menjelaskan proses evaluasi konsumen. Pertama, konsumen berusaha memenuhi kebutuhan. Kedua konsumen mencari manfaat tertentu dari solusi produk. Ketiga, konsumen memandang masing-masing produk sebagai sekumpulan atribut dengan kemampuan yang berbeda-beda dalam memberikan manfaat untuk memuaskan kebutuhan.

4. Keputusan Pembelian

Keputusan pembelian merupakan tahap dalam proses pengambilan keputusan pembeli dimana konsumen benar-benar menetapkan keputusan untuk membeli produk. Pada tahap evaluasi, para konsumen membentuk preferensi atas merek-merek yang ada di 
dalam kumpulan pilihan kemudian konsumen tersebut membentuk niat untuk membeli merek yang paling disukai. Diantara niat pembelian dan keputusan pembelian menurut Kotler (2016:227) ada dua faktor diantara niat pembelian dan keputusan pembelian:

a. Motivasi atau sikap orang lain memberikan pengaruh bagi alternatif yang disukai konsumen, memotivasinya untuk menuruti keinginan orang lain.

b. Situasi yang tidak terantisipasi dapat muncul dan mengubah niat pembelian.

5. Perilaku Pasca Pembelian

Perilaku pasca pembelian merupakan tahap dalam proses pengambilan keputusan pembeli dimana konsumen mengambil tindakan lebih lanjut setelah membeli berdasarkan kepuasan atau ketidakpuasaan yang mereka rasakan. Setelah membeli produk, konsumen akan mengalami level kepuasan atau ketidak puasan tertentu. Tugas pemasar tidak berakhir begitu saja ketika produk dibeli. Para pemasar harus memantau kepuasan pasca pembelian, tindakan pasca pembelian, dan pemakaian produk pasca pembelian.

a. Kepuasan Pasca Pembelian

Kepuasan pembeli merupakan fungsi dari seberapa dekat harapan pembeli terhadap produk dengan kinerja yang dirasakan pembeli atas produk tersebut.

\section{b. Tindakan Pasca Pembelian}

Kepuasan dan ketidakpuasan terhadap produk akan mempengaruhi perilaku konsumen selanjutnya. Apabila konsumen tersebut puas maka akan menunjukkan kemungkinan yang lebih tinggi untuk membeli kembali. Konsumen yang tidak puas mungkin tidak akan menggunakan produk itu lagi atau mereka mungkin mengambil tindakan publik seperti mengajukan keluhan ke perusahaan tersebut, mengadu pada kelompok-kelompok lain. 


\section{METODE PENELITIAN}

\section{Desain Penelitian}

Penelitian ini mencoba untuk meminta orang-orang untuk mengungkapkan berbagai pikiran mereka tentang suatu topik tanpa memberi mereka banyak arahan atau pedoman bagaimana harus berkata apa. Sedangkan jenis penelitian yang digunakan dalam penelitian ini adalah fenomenologi. Dalam penelitian ini, jenis penelitian fenomenologi dipilih karena pengalaman-pengalaman yang dirasakan para konsumen Go-Jek dalam menggunakan Go-Jek dapat dikatakan selalu berbeda. Hal yang membuat berbeda tentunya bukan dari Go-Jek itu sendiri melainkan lebih pada bagaimana perilaku konsumen dalam menggunakan jasa transportasi ojek online Go-Jek. Oleh karena proses penggunaan dipengaruhi banyak faktor, sehingga menyebabkan pembentukan perilaku masing-masing konsumen dalam menggunakan jasa transportasi ojek online Go-Jek menjadi berbeda.

\section{Setting Penelitian}

Setting penelitian adalah cakupan wilayah yang menjadi basis penelitian. Dalam penelitian ini lokasi penelitian di kota Semarang yang ditentukan secara sengaja (purposive), karena banyaknya konsumen jasa transportasi di kota Semarang ada sebagian yang mengonsumsi atau menggunakan jasa transportasi ojek online Go-Jek.

\section{Pemilihan Informan}

Dalam penelitian ini teknik sampling yang digunakan adalah purposive sampling dan dilanjutkan menggunakan snowball sampling. Purposive sampling adalah metode penetapan sampel dengan berdasarkan pada kriteria-kriteria tertentu. Sedangkan snowball sampling adalah teknik pengambilan sampel yang pada mulanya berjumlah kecil tetapi makin lama makin banyak dan akan berhenti ketika informasi yang didapatkan cukup.

Dari penjelasan di atas, maka kriteria pemilihan informan didasarkan pada empat hal, yaitu sebagai berikut:

1. Informan berusia 19 tahun ke atas. 
2. Informan merupakan pengguna smartphone

3. Informan memiliki aplikasi Go-Jek pada smartphone mereka.

4. Informan pernah memesan layanan di aplikasi Go-Jek

\section{Tabel 3.1}

\section{Daftar Informan}

\begin{tabular}{|c|l|l|}
\hline No & \multicolumn{1}{|c|}{ Nama } & \multicolumn{1}{c|}{ Keterangan } \\
\hline 1 & Veronica Mutisari & Konsumen jasa transportasi ojek online Go-Jek \\
\hline 2 & Eri Nofitasari & Konsumen jasa transportasi ojek online Go-Jek \\
\hline 3 & Nurul Hidayat & Konsumen jasa transportasi ojek online Go-Jek \\
\hline 4 & Suci Indriyani & Konsumen jasa transportasi ojek online Go-Jek \\
\hline 5 & Riyadi Nugroho & Konsumen jasa transportasi ojek online Go-Jek \\
\hline
\end{tabular}

\section{Metode Pengumpulan Data}

Metode pengumpulan data dalam penelitian ini adalah Wawancara, pengamatan Berperanserta (Participant Observation), Telaah Catatan Organisasi (Document Records), Triangulation dan Member Check.

\section{Teknik Analisis}

Dalam menganalisis data yang diperoleh dari data, baik primer maupun sekunder, metode penelitian yang dipergunakan adalah metode analisa deskriptif kualitatif dengan metode perbandingan tetap atau Constant Comparative Method, karena dalam analisa data, secara tetap membandingkan kategori dengan kategori lainnya.

\section{Data Reduction}

1. Organisasi Data - Menentukan Kategori, Konsep, Tema dan Pola (Pattern)

2. Pengelompokan Data

3. Pemahaman (Understanding) dan Mengujinya

4. Interpretasi 


\section{HASIL PENELITIAN DAN PEMBAHASAN}

\section{Profil Informan}

\section{Tabel 4.1}

\section{Daftar Informan}

\begin{tabular}{|c|l|l|}
\hline No. & \multicolumn{1}{|c|}{ Nama } & \multicolumn{1}{c|}{ Keterangan } \\
\hline 1 & Veronica Mutisari & Konsumen jasa transportasi ojek online Go-Jek \\
\hline 2 & Eri Nofitasari & Konsumen jasa transportasi ojek online Go-Jek \\
\hline 3 & Nurul Hidayat & Konsumen jasa transportasi ojek online Go-Jek \\
\hline 4 & Suci Indriyani & Konsumen jasa transportasi ojek online Go-Jek \\
\hline 5 & Riyadi Nugroho & Konsumen jasa transportasi ojek online Go-Jek \\
\hline
\end{tabular}

\section{Pembahasan}

A. Pertanyaan tentang "Faktor-faktor apa saja yang mendasari konsumen memilih jasa transportasi ojek online Go-Jek ?"

\section{- Faktor Internal}

\section{- Faktor Pribadi}

1) Apakah Anda dalam menggunakan jasa transportasi ojek online Go-Jek di pengaruhi oleh faktor usia ? Jelaskan !

Berdasarkan kutipan hasil wawancara dari semua informan penelitian, maka dapat disimpulkan bahwa usia tidak mempengaruhi keputusan pembelian. Artinya bahwa semakin tua usia seseorang tidak berpengaruh terhadap keputusan pembelian yang semakin tinggi pada layanan jasa transportasi ojek online Go-Jek.

2) Apakah Anda dalam menggunakan jasa transportasi ojek online Go-Jek di pengaruhi oleh faktor latar belakang pendidikan ? Jelaskan!

Berdasarkan jawaban semua informan dalam penelitian ini, yang ditulis dalam bentuk kutipan hasil wawancara, maka dapat diketahui bahwa latar belakang pendidikan tidak mempengaruhi keputusan pembelian layanan jasa transportasi ojek online Go-Jek. Hal ini berarti semakin tinggi tingkat pendidikan seseorang, maka seseorang tetap tidak mempengaruhi untuk memutuskan menggunakan layanan jasa transportasi ojek online Go-Jek. Dengan kata lain, informan dalam 
penelitian ini tidak mempertimbangkan latar belakang pendidikannya saat memutuskan untuk menggunakan jasa transportasi ojek online Go-Jek.

\section{3) Apakah Anda dalam menggunakan jasa transportasi ojek online Go-Jek di} pengaruhi oleh faktor pekerjaan ? Jelaskan !

Kutipan jawaban dari seluruh informan penelitian ini memperlihatkan bahwa pekerjaan merupakan salah satu hal yang dapat mempengaruhi keputusan pembelian seseorang atau konsumen. Artinya jika semakin khusus atau spesifik pekerjaan seseorang, maka seseorang tersebut semakin membeli barang atau jasa sesuai dengan pekerjaannya itu.

4) Apakah Anda dalam menggunakan jasa transportasi ojek online Go-Jek di pengaruhi oleh faktor gaya hidup ? Jelaskan !

Pernyataan dari seluruh informan dalam penelitian ini memperlihatkan bahwa gaya hidup seseorang mempengaruhi keputusan pembelian, artinya bahwa gaya hidup dijadikan oleh konsumen sebagai bahan pertimbangan dalam keputusan penggunaan jasa transportasi ojek online Go-Jek.

\section{- Faktor Psikologis}

1) Apakah Anda dalam menggunakan jasa transportasi ojek online Go-Jek di pengaruhi oleh faktor sifat maupun kepribadian ? Jelaskan!

Berdasarkan kelima kutipan jawaban informan dalam penelitian ini, maka dapat diketahui bahwa sifat atau kepribadian tidak berpengaruh terhadap keputusan pembelian. Artinya sifat atau kepribadian seperti apapun yang dimiliki oleh seseorang tidak membuat orang memutuskan untuk menggunakan jasa transportasi ojek online Go-Jek.

2) Apakah Anda dalam menggunakan jasa transportasi ojek online Go-Jek di pengaruhi oleh faktor rasa suka ? Jelaskan !

Berdasarkan kutipan jawaban dari informan penelitian, maka dapat dikatakan rasa suka atau kesukaan seseorang juga dapat mempengaruhi keputusan pembeliannya. Hal ini berarti semakin suka seseorang terhadap layanan jasa Go-Jek, maka semakin besar pula keputusan penggunaan layanan jasa Go-Jek, begitupun sebaliknya. 
3) Apakah Anda dalam menggunakan jasa transportasi ojek online Go-Jek di pengaruhi oleh faktor pengalaman masa lalu ? Jelaskan !

Beberapa kutipan jawaban yang berasal dari semua informan memperlihatkan bahwa pengalaman masa lalu seseorang atau konsumen berpengaruh terhadap keputusan untuk melakukan pembelian. Artinya semakin baik pengalaman masa lalu dalam penggunaan layanan jasa Go-Jek yang dialami atau dirasakan konsumen, maka semakin besar pula keputusan penggunaan layanan jasa Go-Jek di masa datang oleh konsumen, begitu sebaliknya.

\section{- Faktor Eksternal}

\section{- Faktor Budaya}

1) Apakah Anda dalam menggunakan jasa transportasi ojek online Go-Jek di pengaruhi oleh faktor budaya ? Jelaskan !

Seluruh kutipan hasil wawancara dari informan dapat disimpulkan bahwa faktor budaya tidak berpengaruh terhadap keputusan pembelian layanan jasa transportasi online Go-Jek.

\section{- Faktor Sosial}

1) Apakah Anda dalam menggunakan jasa transportasi ojek online Go-Jek karena dibujuk maupun diajak oleh teman ? Jelaskan !

Semua kutipan jawaban yang berasal dari informan dalam penelitian ini menunjukkan bahwa faktor teman yang merupakan bagian dari kelompok referensi dapat mempengaruhi keputusan pembelian. Artinya semakin teman membujuk atau mengajak seseorang untuk menggunakan layanan Go-Jek, maka seseorang tersebut semakin besar keputusan pembeliannya terhadap layanan Go-Jek.

2) Apakah Anda dalam menggunakan jasa transportasi ojek online Go-Jek karena dibujuk maupun diajak oleh anggota keluarga Anda seperti ayah, ibu, kakak, adik, maupun sepupu ? Jelaskan !

Berdasarkan pernyataan yang diungkapkan oleh semua informan seperti yang terdapat dalam kutipan dalam wawancara memperlihatkan bahwa faktor keluarga tidak mempengaruhi keputusan penggunaan layanan Go-Jek. 
3) Apakah Anda dalam menggunakan jasa transportasi ojek online Go-Jek di pengaruhi oleh status sosial atau jabatan dalam masyarakat ? Jelaskan!

Berdasarkan kutipan hasil wawancara dari informan penelitian ini, maka dapat disimpulkan bahwa status sosial seseorang dalam masyarakat tidak mempengaruhi seseorang atau individu dalam keputusan penggunaan layanan jasa transportasi ojek online Go-Jek.

\section{- Faktor Komunikasi Pemasaran}

1) Apakah Anda dalam menggunakan jasa transportasi ojek online Go-Jek di pengaruhi karena banyaknya promosi menarik dari pihak Go-Jek ? Jelaskan !

Berdasarkan beberapa pernyataan seperti yang terdapat dalam kutipan jawaban informan dalam penelitian ini, maka dapat disimpulkan bahwa promosi berpengaruh terhadap keputusan penggunaan layanan jasa transportasi Go-Jek. Jika semakin sering promosi dilakukan oleh pihak Go-Jek, maka cenderung semakin besar keputusan penggunaan layanan jasa transportasi ojek online Go-Jek.

2) Apakah Anda dalam menggunakan jasa transportasi ojek online Go-Jek di pengaruhi karena harganya ? Jelaskan !

Berdasarkan kutipan jawaban dari seluruh informan dalam penelitian ini memperlihatkan bahwa harga memang mempengaruhi keputusan pembelian seseorang. Artinya semakin mahal harga atau tarif layanan Go-Jek, maka cenderung keputusan penggunaan layanan Go-Jek oleh konsumen semakin rendah, sebaliknya semakin murah atau terjangkau harga atau tarif layanan Go-Jek maka semakin besar keputusan penggunaan layanan jasa transportasi Go-Jek.

3) Apakah Anda dalam menggunakan jasa transportasi ojek online Go-Jek di pengaruhi karena ketersediaan layanan mudah diperoleh ? Jelaskan!

Berdasarkan kutipan jawaban dari para informan, maka dapat disimpulkan bahwa ketersediaan layanan mempengaruhi keputusan penggunaan layanan Go-Jek, dengan kata lain ketersediaan layanan akan 
sangat dipertimbangkan oleh individu ketika sebelum menggunakan layanan jasa transportasi ojek online Go-Jek.

4) Apakah Anda dalam menggunakan jasa transportasi ojek online Go-Jek di pengaruhi karena adanya asuransi kecelakaan ? Jelaskan !

Berdasarkan kutipan jawaban dari para informan, maka dapat disimpulkan bahwa asuransi kecelakaan tidak mempengaruhi keputusan penggunaan layanan jasa Go-Jek, dengan kata lain asuransi tidak dipertimbangkan oleh individu ketika menggunakan layanan jasa ojek online Go-Jek.

\section{Teori Mini Faktor yang Mempengaruhi Perilaku Konsumen dalam Menggunakan Jasa Transportasi Ojek Online Go-Jek}

Dari berbagai temuan dalam penelitian ini, faktor yang mempengaruhi perilaku konsumen dalam menggunakan jasa transportasi ojek online Go-Jek dapat digambarkan seperti di bawah ini:

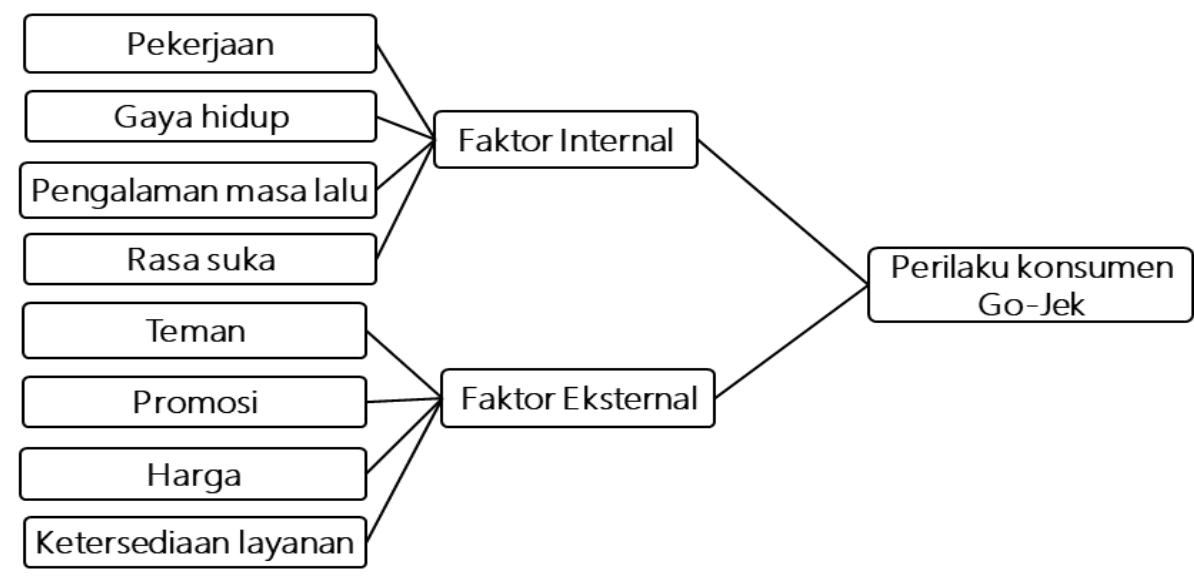

Gambar 4.1 Pola faktor yang mempengaruhi perilaku konsumen jasa transportasi ojek online Go-Jek

(Sumber: Data primer)

Dari gambar diatas dapat dilihat bahwa perilaku konsumen dalam menggunakan jasa transportasi ojek online Go-Jek dipengaruhi oleh dua faktor utama yaitu, faktor internal dan faktor eksternal. Dimana faktor internal merupakan faktor yang berasal dari dalam individu (informan) itu sendiri, yaitu meliputi 
pekerjaan, gaya hidup, pengalaman masa lalu dan rasa suka. Sedangkan faktor lainnya adalah faktor eksternal yang berasal dari luar atau lingkungan individu (informan) itu sendiri, yaitu meliputi teman, promosi, harga dan ketersediaan layanan.

\section{KESIMPULAN DAN SARAN}

\section{Kesimpulan}

Berdasarkan hasil wawancara dengan informan dalam pembahasan pada bab sebelumnya, maka dapat diambil kesimpulan sebagai berikut:

1. Faktor Internal yang mempengaruhi informan dalam keputusan penggunaan jasa transportasi ojek online Go-Jek adalah pekerjaan, gaya hidup, pengalaman masa lalu dan rasa suka.

2. Faktor Internal yang tidak mempengaruhi informan dalam keputusan penggunaan jasa transportasi ojek online Go-Jek adalah usia, pendidikan dan sifat atau kepribadian.

3. Faktor Eksternal yang mempengaruhi informan dalam keputusan penggunaan jasa transportasi ojek online Go-Jek adalah teman, promosi, harga dan ketersediaan layanan.

4. Faktor Eksternal yang tidak mempengaruhi informan dalam keputusan penggunaan jasa transportasi ojek online Go-Jek adalah budaya, keluarga, status sosial atau jabatan dan asuransi kecelakaan.

\section{Saran}

Berdasarkan kesimpulan diatas, saran yang dapat diberikan oleh peneliti adalah sebagai berikut:

1. Bagi pihak perusahaan jasa transportasi ojek online Go-Jek hendaknya mempertimbangkan faktor internal seperti pekerjaan, gaya hidup, pengalaman masa lalu dan rasa suka serta faktor eksternal seperti teman, promosi, harga dan ketersediaan layanan yang mempengaruhi konsumen dalam menggunakan jasa transportasi ojek online Go-Jek semakin meningkat dimasa mendatang. 
2. Bagi peneliti selanjutnya hendaknya menambahkan variabel lain untuk dianalisis seperti atribut merek, bauran pemasaran jasa dan sebagainya.

\section{Keterbatasan Penelitian}

Penelitian ini sudah diupayakan semaksimal mungkin, namun masih terdapat banyak keterbatasan, antara lain:

1. Penelitian ini masih belum bisa mengungkapkan secara keseluruhan faktor-faktor yang mempengaruhi perilaku konsumen dalam menggunakan jasa transportasi ojek online Go-Jek misalnya atribut merek, bauran pemasaran jasa dan faktor-faktor lain yang tidak diteliti dalam penelitian ini.

2. Penelitian ini informannya terbatas karena hanya lima orang informan, jadi hasil penelitian ini mempunyai tingkat generalisasi untuk umum yang rendah, dan hanya untuk referensi civitas akademik saja.

\section{Rekomendasi}

Berdasarkan hasil penelitian yang telah dilakukan, maka terdapat beberapa rekomendasi sebagai berikut:

1. Untuk diteliti ulang dengan latar metode penelitian yang sama yaitu dengan metode penelitian kualitatif.

2. Menguji hasil temuan teori mini dengan menggunakan metode penelitian kuantitatif.

\section{DAFTAR PUSTAKA}

Arep Ishak dan Tanjung Hendri. 2003. Manajemen Kompensasi. Jakarta: Gramedia Widiasarana Indonesia.

Armstrong, M, 1998, Performance Management. England: Clays,Ltd,St.Ives ple Brahmasari, Ayu, Ida. 2005, Pengaruh Motivai Kerja, Kepemimpinan dan Budaya Organisasi Terhadap Kepuasan Kerja Karyawan Serta Dampaknya Pada 
Kinerja Perusahaan (Studi Kasus Pada PT. Hai Intenational Wiratama Indonesia), Pasca Sarjana Universitas 17 Agustus Surabaya.

Dessler, G. 1997. Manajemen Personalia. Edisi 3. Terjemahan Agus Dharma. Jakarta: Erlangga.

Mangkunegara, Anwar Prabu. 2002. Manajemen Sumber Daya Manusia Perusahaan. Bandung: Remaja Rosdakarya.

Mar'at, 1983, Pemimpin dan Kepemimpinan, Jakarta: Ghalia Indonesia.

Nawawi, Hadari, 1993, Kepemimpinan yang Efektif. Yogyakarta: Gadjah Mada University Press,

Robin, P. Stephen. 2003. Organizatioanal Behavior. $9^{\text {th }}$ Edition. New Jersey: Precentice Hall International Inc.

Siagian, Sondang P, 2003, Teori dan Praktek Kepemimpinan. Jakarta: PT. Bina Aksara,.

Stephen C. Harper , 2002, Seri Manajemen Sumber Daya Manusia “ Kinerja / Performance " (Ed), Pendekatan Pengembangan terhadap Penilaian Kinerja, Jakarta: PT. Elex Media Komputindo-Kelompok Gramedia.

Sudjana, 1991, Metoda Statistika. Bandung: Penerbit Tarsito

Suprihanto. 2003. Penilaian Kinerja dan Pengembangan Karyawan. Jakarta: BPFE

Suharsimi Arikunto. 1997. Metodologi Penelitian Suatu Pengantar. Jakarta: Rineka Cipta.

Sutrisno Hadi. 1997. Statistik. Yogyakarta: Fakultas Psikologi Universitas Gadjah Mada. 
Majalah Ilmiah Solusi

Vol. 16, No. 4 Oktober 2018

ISSN : 1412-5331 